\title{
Marketing Constraints to Goats in the Western Hill of Nepal
}

\author{
Megh B. Nepali*1 ${ }^{1}$, Megh R. Tiwari ${ }^{3}$, Sudha Sapkota ${ }^{2}$, Hari P. Poudel ${ }^{3}$, Budhi R. Acharya ${ }^{3}$ and \\ Sudeep Gautam ${ }^{1}$ \\ ${ }^{1}$ Socio Economics and Agricultural Research Policy, Division, Khumaltar \\ ${ }^{2}$ Nepal Agricultural Research Council, Singha Durbar \\ ${ }^{3}$ Regional Agricultural Research Station, Lumle
}

\begin{abstract}
Goat marketing study was conducted in eleven districts with the objectives of exploration the existing goat marketing system in western hills of Nepal. The methodology of the study was households survey, Rapid Marketing Appraisal and use of secondary data. Some of the marketing centers are at the village level, catchments, terminal level markets and district headquarters. There are some marketing agents dealing with the goat marketing from village to the municipalities. Goat marketing agents mainly found farmers and middlemen at the village level and catchments markets. In terminal markets mainly wholesalers and middlemen were involved where as in district headquarters and municipalities middlemen, wholesalers and butchers were dealing the goat business. 59.3\% respondents believed that middlemen visit in the village for goat marketing. Almost all farmers sell their goats on the basis of estimated price. Major constraints on goat marketing were lack of public goat marketing centres, lack of communications about goat marketing and lack of infrastructure etc in all the domestic markets. In the western hills of Nepal main goat marketing centre was found in Pokhara sub municipality where traders/whole sellers bring their goats to sale from different catchments. Government has the provision of establishing new goat marketing centers in each VDCs and district headquarters.
\end{abstract}

Key words: Agents, collection, demand, price, transportation

\section{INTRODUCTION}

Goat farming is an important component of subsistence farming system in the western hills of Nepal for cash generation of resource poor farmers who are unable to invest in large ruminants. Most farmers raise goats because the demand of goat is high throughout the year. Currently goat marketing management in Nepal is poor, which is creating the problem of over and under supply in different times and places. Raising different breeds of goats is commonly practiced under the traditional management either in sedentary or migratory system in the rural areas of Nepal. While looking at market situation of goat in the remote rural area, the price hiking is chaotic. Goat market price is not uniform. Demand of goat is high not only in the festival time but also throughout the year. When there is high demand, question arises why it is not possible to fulfill the demand domestically. Every year Nepal imports about 266 thousand goats either from India or Tibet to fulfill the demand of goat meat (Ministry of Finance 2006).

For the improvement of living standard of hill and mountain people Agricultural Prospective Plan (1995) has given considerable emphasis on improvement in livestock production especially milk and meat which might improve the cash generating opportunity of the farming families. APP (1995) has estimated the contribution of livestock GDP (Gross Domestic Production) to increase from $31 \%$ of before APP level to $45 \%$ in the last period of APP in which the highest growth is estimated in the mountains and hills regions of the country. As envisaged in APP, NARC has given priority for Goat Research Program. However, despite of 7.4 million goats in the country, the urban need is generally met with import from the neighboring countries.

Most of the farmers in the western hills raise either local Khari or improved goat, in a flock or a few in their home yard or in stall feeding system. The total number of goats in Nepal is 7,421624, 
however in western hills of Nepal the goats population is 995,144 (MoAC 2002). Goat meat production in Nepal is 42,820 mt in 2006. During FY2002/003, meat production was increased by 2.5 percent and reach to the level of $204000 \mathrm{mt}$. Goat contributed about 12\% to livestock GDP. Economic return from goat farming is comparatively higher than other sector of livestock (Pandey 1998). The average income from goat sale was estimated to be Rs 11,299 per household (Thakur et al 2003). If proper production and marketing supports are provided, there is vast potential for growth of goat enterprises in Nepal. After buffalo, goat is a second biggest source of meat in Nepal. In such situation the organized marketing network is virtually lacking in the country. Total amount of Nepalese currency that goes India from Nepal appears to 50 crores each year (Kharel 2000). The western zone does not have large, organised goat markets of the number and size as in the eastern and central zone. Animal protein is supplied by the goat to human being, without competing with humans for cereal grains. The goat is a prolific animal and can be raised cheaply by the farming households. Under sedentary management system $65 \%$ goats were raised, Livestock management Plan (1993) of which more than 50\% are reared in the hills. Farmers were getting the price of their goat even the less than the cost of production though consumers are paying high price for the goat meat. In order to understand the marketing problem, this research was conducted in western hill districts to collect information from rural farmers, middlemen, wholesaler, butchers and consumer.

\section{METHODOLOGY}

Data were collected from 11 districts (Gorkha, Lamjung, Tanahaun, Kaski, Syanga, Palpa, Arghakhanchi, Gulmi, Baglung, Parbat and Myagdi) using the Participatory Rural Appraisal (PRA) and Rapid Marketing Appraisal (RMA) checklist as well as household questionnaires for the study in 2003. Four goat raising VDC's from each district were purposively selected with the consultation of District Livestock Offices from each district. In each VDC one goat-raising ward was selected on the basis of commercial goat raising. From the each ward about 5\% commercial goat raisers were randomly selected for the interview. In the case of consumers in urban areas information was collected from different institutions specially police camp, army camp, boarding school, hospitals, hotels and restaurants and 20 respondents from other consumers randomly selected from each district. Similarly, the information was collected from middlemen, wholesalers, retailers, traders, market centre and catchments in each district in clusters. The data was tabulated, cross tabulated and analyzed in excel program.

\section{FINDINGS}

\section{General socio-economic information}

In the study area, family size ranged from 6 to 8 , with a mode household size 6 . Male and female ratio is about equal. In the surveyed area average land holding in khet land is 4.68 Ropani, Bari land 5.36 Ropani, Bhir land 3.32 Ropani and pasture land 3.51 Ropani. Farmers were generating household income per annum from different sources. Figure 3 gives the percentage of different sources of income. Income derived from goat is $11 \%$, fruit $4 \%$, vegetables $3 \%$, cereal $18 \%$, remittance $14 \%$, labor $5 \%$, pension $10 \%$, service $27 \%$ and from other animals $8 \%$ (Figure 1).

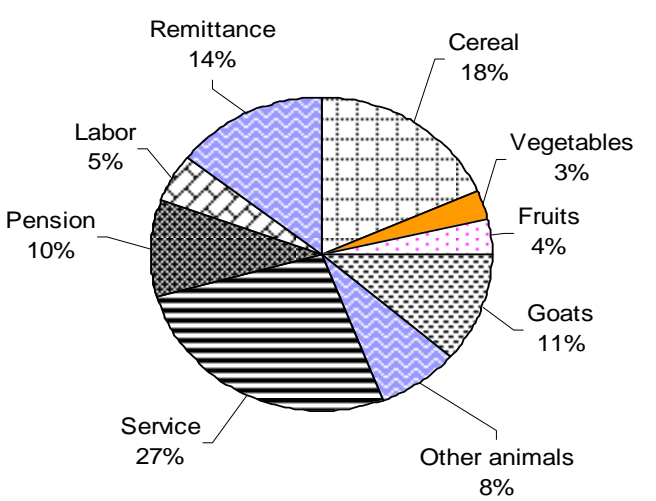

Figure 1. Average income generation per year. 


\begin{tabular}{|c|c|c|c|c|c|c|c|c|c|c|c|}
\hline Average & Arghakhachi & Palpa & Gulmi & Syangja & Parbat & Kaski & Baglung & Myagdi & Lamjung & Gorkha & Tanahun \\
\hline Family size & 7 & 8 & 7 & 7 & 6 & 6 & 7 & 6 & 6 & 6 & 6 \\
\hline \multicolumn{12}{|l|}{ Landholding (Ropani) } \\
\hline Khet land & 6 & 2 & 4 & 4.5 & 8 & 4 & 3 & 5 & 6 & 6 & 3 \\
\hline Bari land & 7 & 5 & 14 & 5 & 3 & 2 & 3 & 5 & 2 & 7 & 6 \\
\hline Bhir land & 9 & 4 & 4 & 1 & 2 & - & 0,1 & 13.5 & 1 & 1 & 1 \\
\hline Pasture land & 20 & 4 & 1 & 2,2 & 1 & 0.5 & 0.6 & 1 & 1 & 0.3 & 7 \\
\hline $\begin{array}{l}\text { Goat population per } \\
\text { households }\end{array}$ & 9 & 7 & 8 & 6 & 3 & 7 & 3 & 6 & 11 & 8 & 7 \\
\hline $\begin{array}{l}\text { Sales of goats per } \\
\text { households per year } \\
\text { Market agents }\end{array}$ & 3 & 3 & 2 & 2 & 2 & 4 & 2 & 2 & 2 & 1 & 2 \\
\hline Wholesalers & 2 & 2 & 1 & 4 & 1 & 14 & 2 & 1 & 2 & 2 & 2 \\
\hline Middleman & 4 & 6 & 4 & 4 & 5 & 6 & 4 & 4 & 4 & 4 & 4 \\
\hline Butchers & 6 & 8 & 11 & 6 & 9 & 36 & 9 & 6 & 4 & 5 & 6 \\
\hline $\begin{array}{r}\text { Villages } \\
\text { Catchments }\end{array}$ & 986 & 1440 & 2160 & 96 & 0 & 3240 & 720 & 900 & 1080 & 216 & 334 \\
\hline \multicolumn{12}{|l|}{ Others } \\
\hline & 1406 & 2322 & 1242 & 1542 & 2337 & 18522 & 2323 & 1550 & 1602 & 2321 & 1576 \\
\hline
\end{tabular}

\section{Goat marketing system}

Goat marketing survey was conducted in 11 western hill districts of Nepal in the farming system of agriculture based livestock as well as agro-forestry in the different agro ecological zones ranging from 250-2300 meters above the sea level which covers river basin, low hills, mid hills and high hills (Nepali et al 1998). Most of the farmers are raising their goats either in grazing or stall feeding in the western hills of Nepal. The supply of goat is not meeting the demand of goat meat. In the study area goats were marketed through different marketing channels. When we discuss the marketing channels these consist of local markets, catchments/ terminal markets, district market and municipality market. A local level village market is the market where goat producer sale their goats with in the village for consumption or breeding purpose as well as to the middleman. This study resulted that about $61 \%$ goats were sold with in the village markets. Middlemen and farmers were the other marketing agents to collect goats from different villages and made sales them to the catchments markets. Wholesalers purchase goats from terminal markets to supply goats. Chanauta, Butawal, Mugling and Lother from where wholesalers load the goats on bus roof or use trucks to transport goats to Pokhara. District headquarters markets and municipalities were the main marketing centres where wholesaler and middlemen supply the goats for marketing. Pokhara submunicipality market is the main goat marketing centre in Western Nepal. The study revealed that there is lack of public goat marketing centres either at the village level or in the district headquarters and municipality.

\section{EXISTING GOAT MARKET CHANNELS}

In the existing goat marketing system in western hills it consists of farmers, wholesaler, middlemen, retailers and consumers. A wholesaler deals with the business of more than 40 goats collecting from the catchments market and terminal markets and transport them to the district head quarters. The wholesalers made sale to the retailers and sometimes middleman at a time where as middlemen deal with small numbers (10 to 15$)$ of goats collecting from house to house. The retailers deal with the business of few goats collecting from the neighboring villages or purchase a few goats from the wholesaler/middleman then slaughter the goats and sale meat to the consumers. In the existing goat marketing system in many cases farmers themselves were involved for the sales of goats within the village. Wholesalers and middlemen were purchasing $46.96 \%$ of goats in the villages and middlemen were very near to them for collecting from the villages and selling them in headquarters areas (Table 1). Besides middlemen, retailers too were involved in goat marketing because they were the one who collect local goats and bring them in district headquarters and sale meat in share price not in weight because consumers preferred such type of meat even though the price is high. In the surveyed area wholesaler, middlemen, butchers and farmers were involved for the goat marketing. Figure 1 illustrates the major goat marketing channels. Goats were marketed by the wholesalers $46.96 \%$, middlemen $45.34 \%$, butchers $4 \%$ and others $3.7 \%$ respectively. 


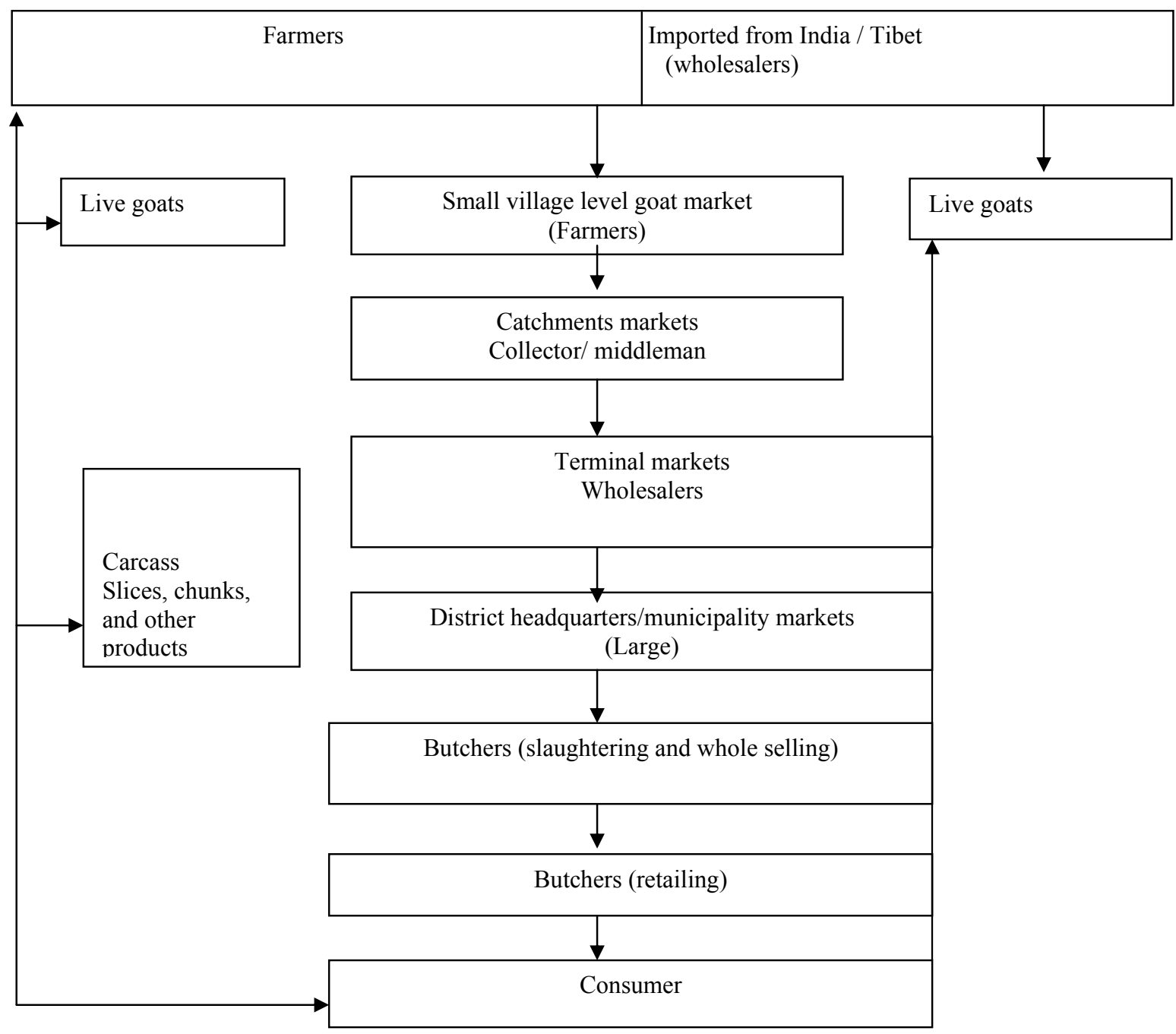

Figure 2. Major goat marketing channels in the western hills of Nepal.

Goat marketing centres and catchments

In the study area, although there is no marketing infrastructure existed in public sector either in the VDCs level or in district headquarters and municipalities, the goats produced were marketed through unorganized marketing centers. There are some marketing agents in the goat production area such as local markets, catchments (where farmers bring their goats on the way to market)/terminal markets (goats are collected to transport to the large markets), district market and municipality market. This study resulted that about $61.7 \%$ goats were sold with in the village markets. Middlemen and farmers collect goats from different villages and made sales them to the catchments markets.

There are some terminal markets from where the wholesalers purchase goats from the middleman and supply to the district headquarters and municipalities. From the terminal markets wholesalers load the goats on bus roof or use trucks to transport goats to Pokhara as well as other district headquarters. District headquarters markets and municipalities are the main marketing centers. According to the wholesalers they were bringing the goats from Lahan, Lother, Arghakhachi, Dang, 
Surkhet, Jagarkot, Sallyan, Myagdi, Butawal and supply to the district headquarters and municipality markets. Traditional traders especially Muslims bring the goats from Indian boarder side such as Kanpur, Lakhnow, Hariana and Punjab. Those traditional traders supply goats to Sandhikharka, Tansen, Putalibazar, Walling, Damauli, Pokhara, Kushma, Baglung and Beni. Besides the Muslims, middlemen, farmers and local butchers also supply goats in the district headquarters. Local butchers purchase goats either from catchments or from rural area. Traders from Mustang bring mountain goats in thousand numbers around October to December in Pokhara valley. The mountain sheep and goats cover the local market of Beni, Baglungbazar, Kushmabazer, and Pokhara municipality. Study found that $60 \%$ goats were supplied from India to Nepal specially from Kanpur, Bareli, Lakhnow, Kalpe, Barabanki,Punjab and Hariyana. About 23\% from village and 17\% from catchments goats were supplied to the market area of Western Nepal. Middlemen, farmers and butchers were the main agents to supply goats from catchments and rural areas of Nepal.

\section{Availability of goats in the existing market}

In the study area, especially in district headquarters, the responses of butchers regarding the availability of goats as required were found only $52.82 \%$. This is because of irregular supply of goats either importing from neighboring country or irregular market mechanism in the study area. Goats were available in Kaski district highest $100 \%$ followed by $75 \%$ each in Arghakhachi and Palpa districts. In Kaski district, highest availability was found due to good goat market mechanism. Wholesaler, middlemen and retailers were equally active for the goat marketing in this district.

Goat marketing at farm level

The analysis of data showed that $64 \%$ farmers marketed their goats at the local level, $3 \%$ marketed their goat in district headquarter, $3 \%$ sold to the whole seller, $29 \%$ to the middleman, $1 \%$ at

Municipality. Less than $1 \%$ was sold for breeding purpose and for sacrificing the goat to the god and goddesses (Figure 3).

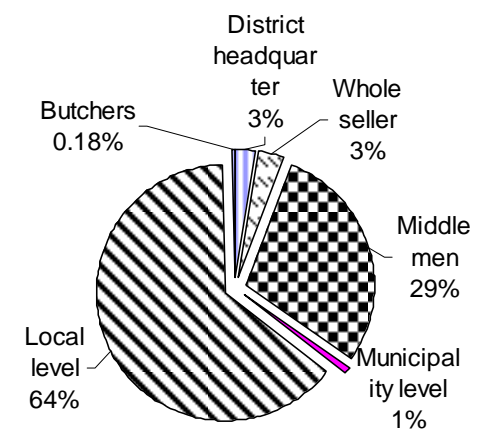

Figure 3. Goat marketing at farm level.

Visit of the middlemen in the village for goat marketing

Visit of the middlemen in the village for goat marketing was one of the important parts of marketing. In Western hills, 59.3\% respondents reported that middlemen visited in the village for goat marketing. In Lamjung district, highest respondents (77\%) reported that middlemen visited frequently in the villages to purchase goats and in Kaski district lowest (28\%) followed by $(42 \%)$ respondents in Parbat district (Table 1).

\section{Average sales of goats per households per year}

Goat keepers were selling their goats in average 2.3 per annum. Responding farmers reported that the selling of goats ranged from 1 to 4 goats per annum per households. Similarly, responding 
farmers reported that they were getting average Rs 3802.6 per annum per household by selling their goats. Annual selling was ranged from Rs 375 to Rs 6023 per households.

Price determination of live goat

In the study area the price of live goat was determined through estimate (looking goat's physical appearance) system. In most cases, goat raising farmers were cheated because they need money immediately to support their family and were bound to sold their goats when the customers visit around their farm yard otherwise they do not have any option to sold their goats because of there is no public goat marketing centres. There was no any mechanism to minimum support price for goat to the goat raising farmers. Due to the lack of marketing centres there was no communication between the farmers and marketing agents related with the goat availability and the price. For price determination, there is bargaining between buyers and sellers but when buyers do cash down then unconsciously farmers accept the given price. In the study area almost farmers sell their goats on the basis of approximation price.

\section{Physical market infrastructure}

In the study area there is lack of physical market infrastructure and weak marketing channels. Specially, the village markets were very weak and hardly functional. When we say village market that is a place having tea shops. Local people get together, where farmers bring their goats around the village tea stalls and grocery shops where they may meet to the middleman or there may be in need of attention program to slaughter the goat and share the meat around the participating villagers. Catchments markets are identified places where the buying and selling of goat takes place in between farmers, middlemen and wholesalers but the date and time was not fixed. Government intervention is needed to occupy the public land and regulate for the marketing centers and strengthen such type of catchments by supporting the fenced. Farmers bring their goats and keep them in it. Physical market infrastructure might be the shelter for marketing agents. Marketing agents may have the facility of balance equipments and other necessary information for goat marketing. In terminal market individual farmers and middleman bring their goats for marketing. It is the identified place but there is lack of marketing physical infrastructure and not regular schedule of date and time of gathering of buyers and sellers may occur. In such markets mainly wholesalers' purchase goats from the middlemen and transport to the municipality and district headquarter markets. Market channels are not regulated and sustainable due to the lack of set of laws and regulations and other government support system.

\section{Transportation of goats from collection to the market centres}

Every year at least 42916 goats were sold in districts headquarters in the study area. About 20158 goats (47\%) were brought from India and 22758 (53\%) goats were collected from different villages. From the different districts the collection of goats around the road access area by the middleman, farmers and butchers transported to district headquarters through either trucks or sometime through the roof of bus. On an average about 200 goats were brought in Pokhara by the wholesaler at a time. The wholesalers/middleman reported that goats were collected from different study area districts. Traditional traders (Muslim) brought goats from India especially from Bareily, Etawah, Kalpi, Lukhnow, Barabanki, Kanpur and Punjab. These goats were supplied in headquarters of western hill districts of Nepal. Traders transported their goats from long distance by using the means of transportation. Mainly middleman and butchers drive their flocks from near villages of the district head quarter where farmers transported their goats to the market centres on foot. Marketing agents were using the vehicles for transportation for collecting goats. In the study area $49 \%$ marketing agents use the means of transportation, $41 \%$ drive the flocks and $10 \%$ agents draw goats by tying rope on neck. The use of means of transportation was high $80 \%$ in Lamjung district followed by $66 \%$ in Myagdi, Gorkha, Parbat and Palpa. Most of wholesalers transport goats from Indian boarder site to the market centres. About $39.64 \%$ butchers and middlemen mainly drive their flocks to the market centres. Driving of flocks was found high in Syangja district (100\%) followed by in Tanahun district (56\%). 


\section{Sanitation of meat stalls (shops)}

In general most of the Nepalese people preferred to consume goat meat even it is more expensive as compared to buffalo meat, pork and chicken. The demand of goat meat during festivals like Dashain, Tihar and ceremony was found higher than in other times.

Especially in districts headquarters the meat stalls were observed regarding the sanitation of the stalls and environments of the surroundings. Better sanitation of the stalls, open and flies around the stalls, and polluted environment around the stalls were taken in to observation. About $55.54 \%$ meat stalls were found in better sanitation, $25.81 \%$ dirty and flies around and $16.90 \%$ were of dirty environment.

\section{Goat marketing constraints}

The marketing constraints existing in Nepal were lack of basic rules like minimum support price to the goat raising farmers, certification for the slaughter, infrastructure of market centres and lack of public awareness about the price of live weight of the goat such as $\mathrm{kg}$. There was not enough well developed infrastructure for animal marketing even at metropolitan cities, sub metropolitan cities, municipalities, district market, and village level markets. Some times the animal may get sick from Pneumonia or lack of shade at night or change in climate/place. In such situation, farmers are bound to sell their goat for whatever price they get. Most of the farmers in rural area are less educated. Therefore, farmers have to loose their expected price. Underdeveloped marketing system was the major marketing constraints besides that production and management constraints were other types. In goat production and management predators, infertility, disease, parasitic, grazing, grass and feed were the other constraints that lead under supply of goats in the markets.

Table 2. Number of respondents involved in different surveyed districts

\begin{tabular}{|c|c|c|c|c|c|c|c|c|c|c|c|}
\hline $\begin{array}{l}\quad \text { Particular } \\
\text { Availability of } \\
\text { goats }\end{array}$ & $\begin{array}{l}\text { Arghakhachi } \\
6(75)\end{array}$ & $\begin{array}{l}\text { Palpa } \\
2(50)\end{array}$ & $\begin{array}{l}\text { Gulmi } \\
6(75)\end{array}$ & $\begin{array}{l}\text { Syangja } \\
4(50)\end{array}$ & $\begin{array}{l}\text { Parbat } \\
3(66)\end{array}$ & $\begin{array}{l}\text { Kaski } \\
36(100)\end{array}$ & $\begin{array}{l}\text { Baglung } \\
1(17)\end{array}$ & $\begin{array}{l}\text { Myagdi } \\
\text { 3(43) }\end{array}$ & $\begin{array}{l}\text { Lamjung } \\
2(50)\end{array}$ & $\begin{array}{l}\text { Gorkha } \\
2(33)\end{array}$ & $\begin{array}{l}\text { Tanahun } \\
2(22)\end{array}$ \\
\hline $\begin{array}{l}\text { Farmers } \\
\text { knowledge on } \\
\text { live weight }\end{array}$ & $74(100)$ & $77(100)$ & $78(90)$ & $83(100)$ & $46(96)$ & $77(100)$ & $74(100)$ & $76(100)$ & $79(100)$ & $79(99)$ & $81(100)$ \\
\hline $\begin{array}{l}\text { Visit of the } \\
\text { middle in the } \\
\text { village }\end{array}$ & $51(69)$ & $59(77)$ & $45(56)$ & $44(53)$ & $19(42)$ & $22(28)$ & $48(65)$ & $29(37)$ & $61(77)$ & $59(74)$ & $60(74)$ \\
\hline $\begin{array}{l}\text { Transportation } \\
\text { of goats }\end{array}$ & $2(25)$ & $4(50)$ & 0 & $4(44)$ & $2(50)$ & $24(30)$ & $1(14)$ & $2(66)$ & $4(80)$ & $2(50)$ & $1(11)$ \\
\hline $\begin{array}{l}\text { Vehicle } \\
\text { Driving flocks }\end{array}$ & $2(25)$ & $3(38)$ & $7(100)$ & $3(33)$ & $2(50)$ & $11(14)$ & $1(17)$ & $1(33)$ & $1(20)$ & $2(50)$ & $5(56)$ \\
\hline Others & $4(50)$ & $1(13)$ & 0 & $2(22)$ & 0 & $2(3)$ & 0 & 0 & 0 & 0 & 0 \\
\hline \multicolumn{12}{|l|}{$\begin{array}{r}\text { Dirty } \\
\text { environment }\end{array}$} \\
\hline & $2(33)$ & 0 & $1(9)$ & $2(25)$ & $3(33)$ & 0 & 0 & $2(33)$ & $1(33)$ & $1(20)$ & 0 \\
\hline
\end{tabular}

\section{CONCLUSION}

Most of the goat raising farmers, marketing agent like middlemen and wholesalers realized that there is lack of proper goat marketing centers in the VDCs level or in district headquarters/ municipalities of western hills of Nepal. There are some weak goat marketing centers and channels functioning from village to the district headquarters. Middlemen, wholesalers and butchers were 
dealing the goat business in district headquarters and municipalities. Regarding the meat stalls, more than fifty percent of the respondents confessed there is lack of proper sanitation. Mainly, goat marketing constraints in western hills are goat production, marketing, appropriate marketing channels, improved breed, predators, infertility, diseases, parasites, grazing land, labors, fodder and forages, concentrate feed and appropriate shed. All the stakeholders including goat raising farmers have to overcome from these constraints through the package of goat production and marketing program which leads to improve the goat marketing condition in Nepal. This study strongly recommended that government should have make policy for the provision of establishing new goat marketing centers in each VDCs and district headquarters. Marketing channels agents' likes wholesaler, middleman and retailers must hold the license to deal business with goat.

\section{ACKNOWLEDGEMENT}

The support of Regional Agricultural Research Station, Lumle for providing an opportunity to carry out this study is gratefully acknowledged. The support of National Agriculture Research and Development Fund (NARDF) for funding this research as a part of project is gratefully acknowledged. We would like to extend our special thanks to Mr IP Gautam, for encouraging proposal writing, carryout the survey and editing this part. Thanks are due to Mr BS Shrestha. Thanks are also due to farmers for their valuable attention and pertinent information during field survey.

\section{REFERENCES}

Kharel M. 2000. Glimpse of goat marketing situation in Nepal. In: Proceedings of the Third Environmentally

Sustainable Livestock Production for Poverty Alleviation Animal Science Convention. Nepal Animal Science Association (NASA). Lalitpur. Nepal.

MoAC. 2002.Statistical information on Nepalese agriculture 2001/2002. Agri-Business Promotion and Statistics Division, Ministry of Agriculture and Cooperatives, Singha Durbar, Kathmandu, Nepal.

MoF. 2006. Annual commodity description. Department of Custom, Ministry of Finance, Government of Nepal. Nepali MB, B Shrestha, RP Bari and KN Dhakal. 1998. Baseline and need identification survey of agroecological research site at Maduwa of Syangja district representing low hills in Western Nepal. Agriculture Research Station, Lumle, NARC, Nepal.

Panday N. 1998. Technical report on gender dynamic in goat production. Outreach Research Division (ORD), Khumaltar, Lalitpur, NARC, Nepal.

Thakur NS, M Joshi, MR Tawari, B Shrestha and L Pandey. 2003. Socio-economic study on goat farming: A case study of command area under RARS (Goat), Bandipur. Outreach Research Division (ORD), Khumaltar, Lalitpur, NARC, Nepal. 